\title{
Local political leadership and the modernisation of local government*
}

\begin{abstract}
Political leadership has been a key element of central government's attempts to 'modernise' local government over the past decade, within a discourse that emphasised 'strong' and 'visible' leadership and the role of leaders and leadership in driving change within local authorities. In the context of such an approach, and also taking account of academic discourse, this article draws upon interviews with nearly thirty individuals in leadership positions in local authorities in England, Scotland and Wales to assess their experiences of leadership and their views of some aspects of the role and work of councils. It suggests that whilst there is broad convergence between the aspirations of government and the narratives that emerge from these leaders on some aspects of local political leadership, there are also differences, perhaps most notably over the relationship between changes to decision making structures and the loci of political power.
\end{abstract}

Following significant structural and other reforms of local government under the Conservative governments of 1979 to 1997, the past decade has seen central government placing a great deal of emphasis upon the 'modernisation' of local government. In England there have been a number of aspects to these reforms including: new council constitutions and decision making structures (leader and cabinet models, or in some cases directly elected mayors) based upon the separation of executive and representative or scrutiny functions, intended to provide a clearer linkage of individuals to policy making and outcomes; performance management and enhancement (Best Value, Comprehensive Performance Assessment and Beacon Councils); an emphasis upon 'community leadership', particularly in a host of new partnership arrangements (such as Local Area Agreements); and the promotion of citizen participation. These changes have been underpinned by the view that local government has been inefficient in providing services and unresponsive to the needs of its citizens, by falling electoral participation, by the continued importance of local government in the delivery of public services, and by a desire for both stronger community leadership (and at the same time involvement in networks and partnership) and for stronger and more individualised leadership of local authorities (for example, Lowndes and Leach, 2004; Laffin, 2008; Rao, 2006). Whilst the government has tended to utilise terms such as 'leaders' and 'leadership' to describe its vision of the role of councils within their communities as well as to the political and managerial leadership of individual authorities, it is the elected political leadership within councils that is the concern of this article.

The role of local political leadership has been a key element of the modernisation agenda at the local level, with the government arguing, for example, that 'Whatever the causes, the Government believes that the failure to maximise the potential of locally elected representatives to act in a leadership role as advocates and champions of local communities is a major obstacle to our ambitions for civil renewal and improved public services' (ODPM, 2005: 13). The government has clearly linked what it sees as a lack of visible leadership with problems of accountability, including through the assumptions that the public know little about how councils make decisions, or who to complain to or how to hold them to account when there are problems, so that the question of leadership has been viewed in tandem with that of political structures (Orr, 2004). The separation of decision making and scrutiny roles, and the attempts to encourage elected mayors, for example, were intended to respond to this perception. In the rest of the United Kingdom the devolved administrations have responsibility for local government, and the pattern of change has been somewhat different, so that in Scotland, for example, greater attention has arguably been paid to reforms to the electoral system for local government, with the introduction of the single transferable vote system for council elections from May 2007, although a number of councils have adopted a leader and cabinet model. 
If discourses inform the ways in which policies and solutions are conceived (Bacchi, 1999) and also provide legitimacy for particular approaches or forms of decision making (Newman, 2001) then they are potentially of significant importance in analyses of policy making and power relations. A number of authors have examined the discourse of New Labour's modernisation generally (for example, Newman, 2001) and in relation to local government, either directly or indirectly (for example, Coulson, 2004; Orr, 2005). It is also possible to identify a number of key elements of the government's discourse around modernisation and political leadership, including the assertions that leadership should be 'strong' and 'visible', and that councillors as a whole should be more diverse and representative of their communities. For example, the government has continued to emphasise that it wishes to see more visible local leadership, and Chapter 3 of the White Paper for England, Strong and Prosperous Communities, included headings such as 'More diverse and representative councillors', 'Councillors as democratic champions', and 'Stronger leadership', all views which recur frequently as part of the New Labour discourse around local government. Under the latter heading, the White Paper stated that 'The Government believes that it is important that councils move towards having more stable and more visible political leadership. Our research shows that leadership is the single most significant driver of change and improvement in local authorities'(DCLG, 2006: 55) and contained a promise to legislate to introduce three models of executive arrangement: a directly elected mayor with a four year term; a directly elected executive with a four year term; or an indirectly elected leader with a four year term. In each of these models the government stated that 'all executive powers will be vested in the mayor or leader' (DCLG, 2006: 55), making that leadership position even more important. The Local Government and Public Involvement in Health Act 2007 enshrined these proposals in legislation and these narratives of reform were again evident in the government's most recent statements on the subject, Strong and Prosperous Communities - The Local Government White Paper Implementation Plan: One Year On (DCLG, 2007), Creating Strong, Safe and Prosperous Communities: Statutory Guidance (DCLG, 2008) and Strong and prosperous communities - The Local Government White Paper: Final implementation plan (DCLG, 2009).

However, whilst it may be possible to identify the consistent framing of ideas about the role and operation of local government in this manner by the government, as Newman notes, different narratives, assumptions and expectations are likely to coexist, and to create 'particularly strong tensions during programmes of reform as deeply embedded institutional norms and rules are challenged by new logics of appropriate action, but no new "rules of the game" have yet been established in practice' (2001: 30-1). One of the questions raised by this article is, therefore, the extent to which the discourse of central government aligns with or differs from that among local political leaders who are the subject of much of it.

Local political leadership has been the focus of an increasingly substantial academic literature in recent years, within which in turn, a number of distinctive narratives can be identified, and the next section briefly reviews some of this, national and international, before the article moves on to draw upon in-depth, largely qualitative interviews, conducted face-to-face or by telephone, with twenty-nine individuals in the second half of 2006. Twenty-one were council leaders or directly-elected mayors and eight were members of cabinets or executives. While not intended to constitute a representative sample, they were drawn from a variety of types of authorities (English districts, counties, unitary authorities and London boroughs, Scottish councils and Welsh councils) with different decision making structures, a variety of forms of political control, and a range of political parties (and Independents). The research sought to reveal the views of respondents on some of the challenges facing local political leaders following 'modernisation'. The article analyses their responses in the context of the discourses outlined above and concludes with a consideration of how and to what extent these different narratives of local political leadership fit together. 


\section{LOCAL POLITICAL LEADERSHIP}

Given that interest and developments around leadership at the local level have been relatively widespread in Europe in recent years, it is unsurprising that there has been the emergence of a considerable literature examining these changes, including of a comparative nature. As with government policy, it is possible to examine the academic discourse, and Orr (2004 and 2005) suggests that there have been different academic narratives of local government change (including the extent to which they are normative and/or analytical), such as those that emphasise continuity between Conservative and New Labour governments and those that focus upon the rhetoric of 'partnership', as well as narratives emerging from within local government.

One important element of the literature is that which reflects the shift to 'governance' and a greater emphasis upon the role of local political leaders. Borraz and John, for example, suggest that with the shift to 'governance', 'Leadership is crucial to the functioning and success of local governance' (2004: 112). They note four, not necessarily incompatible, hypotheses that have been put forward to explain changes in local political executives in much of Western Europe, with the promotion of stronger styles of leadership and local executive functions: firstly, some have seen strong leadership to be a functional response to the institutional fragmentation that characterises urban politics; secondly, the new structures can be seen as reflecting changing values among elites and citizens; thirdly, the move towards stronger local leadership can be seen as providing ideas and models for local elites in the face of increasing powers of the European Union; and fourthly, some form of institutional mimetism or transfer has seen different institutions adopt similar forms in response to the concerns of citizens and policy makers at higher levels of government.

However, whilst each of these hypotheses may have some relevance, they suggest that none are entirely convincing on the basis of the evidence available, and suggest instead three general features, each of which might arguably be said to apply to the position in the United Kingdom, and each of which might be seen as fitting with the discourse of central government: the shift towards stronger leadership 'is first and foremost a response to particular expressions of the 'legitimacy crisis' occurring in local and national politics as expressed by lower electoral turnout and the failure of traditional mechanisms of political accountability' (2004: 108); even if they have increased legitimacy and electoral power, changes in most countries have rarely enhanced the powers of local leaders; 'local leaders vary in their capacity to manage large and complex networks, sets of issues and interest groups' (2004: 108).

Haus and Sweeting also note that leadership is closely linked with issues of local governance, with multi-actor networks seeking to address social problems, thus reflecting narratives around the role of leadership and partnership arrangements. They differentiate between leadership practices ('systematic attempts to enable collective action') and leadership positions ('characterised by institutional provisions of resources and expectations'). As with the discourse that emerges from government, they emphasise the role of leaders, so that 'Although leadership need not be restricted to the incumbents of formal leadership positions, these positions are of crucial importance. They link fluid and innovative processes to formal institutions with clearer lines of accountability - and, of course, they give leaders control over considerable resources in the construction of governance arrangements and in the transformation of local government institutions' (2006: 270).

The appeal of a narrative of 'strong leadership' for governments is further reflected in the work of Mouritzen and Svara (2002), who have argued that it is the form of government that determines the nature of local political leadership, with strong mayors giving the most active forms of leadership, and Goldsmith and Larsen, who suggest that in systems 'where the leader 
of the main political party acts as mayor or council leader, the position provides room for strong minded individuals to exploit their role if they so choose' (2004: 128-9).

Wollmann's work too reflects many of the ideas raised in the government's discourse, suggesting that reform debates across Europe have been driven by concerns to address criticisms of the lack of transparency and accountability within local government, reflected in falling electoral turnout, and because local government is seen as 'less and less capable of coping with evermore complex and wicked social, economic and environmental issues and challenges' (2008: 280).

In the United Kingdom, Gains et al have argued that the changing social and economic environment and the emergence of a networked form of governance is seeing the emergence of 'facilitative leadership' which 'is not about the direct exercise of detailed influence or control over decision making, but rather about giving direction and then mobilizing the resources necessary to ensure that the vision is fulfilled (2007: 12). They also suggest that whilst all three executive models chosen by the government may improve the efficiency of decision making, the mayoral model is most likely to deliver 'facilitative leadership which embraces partnership, is accessible, non partisan and more efficient' (2007: 44), again, very much in line with the government's discourse.

However, there are also alternative narratives which do not align so closely with those emerging from government. For example, Steyvers et al (2008) raise two questions about the transition to stronger executive leadership. Firstly, they ask to what extent attempts to strengthen the executive institutionally actually lead to stronger leadership in practice, and of particular relevance for this article, to what extent do local leaders adapt to such a new role, suggesting that 'it is likely that many leaders still struggle with the challenges these role transformations bring' (Steyvers et al, 2008: 143).

Lowndes and Leach have argued that the structure-led approach to political leadership taken in the Westminster government's reforms 'has not proved wholly effective as a basis for introducing the 'ideal type' of leadership favoured by the government' (2004: 559). Similarly, drawing upon a variety of other work, Leach et al suggest that there are four key elements of leadership: leadership context, with both local and national influences; leadership tasks, including maintaining political support and developing strategic policy directions; leadership skills and capabilities; and leadership effectiveness, again influenced by both local and national agendas. Their research highlighted the range of influences and roles played by leaders, and the diversity of approaches to leadership, and suggested that from a structuralist perspective the new decision making structures 'have so far proved less decisive an influence on political leadership than would have been forecast' and that 'Context and personal capabilities have been equally influential, often more so' (2005: 68). They note that the wishes that are highlighted in the government's discourse, including for leaders who are strong and visible, an emphasis upon external networking and community networking, and a focus on the strategic agenda, had not been fulfilled. For Leach et al, effective local authority political leadership can be characterised 'by the ability to achieve synergy between two separate agendas - the political and the managerial' (Leach et al, 2005: 73) and they argue that the government's continuing emphasis on 'strong' leadership is both too narrow and based upon a view of leadership that is divorced from the variety of contexts and the consequent leadership responses.

Another perspective comes from Copus, who has examined directly elected mayors in England, noting that directly elected mayors can challenge the dominance of party, both in respect of weakening the ties between the mayor and the party, and in seeking alliances and support for issues beyond the confines of party. However, he has also suggested that while mayors may have arisen from changes in political structures, they do not change the power, roles and responsibilities of the council, so that, at present 'English mayors are of the weak 
variety and direct election provides little more than a new route into the top political position on the council' (2004: 18).

Leach and Wilson (2008) too have highlighted the undermining of the power of local party groups (and indeed local parties) and the increasing power of the leader that has arisen from the government's desire for strong, visible leaders, rather than for collective approaches to decision making. A survey of councillors in forty local authorities in England by Rao (2005) also showed the extent of divisions over the power of the leader in the new system, with 46 per cent agreeing that the leader should decide who is in the cabinet, but 43 per cent disagreeing; 60 per cent felt that the leader should have the power to allocate portfolios, but 26 per cent disagreed; and only 12 per cent felt that the leader should decide on policies, with 75 per cent disagreeing.

This brief overview demonstrates that there is a significant strand within academic work on leadership and local government that fits well with the discourse of government since 1997 around strong leadership, including in relation to increasing accountability and legitimacy, and the need to be able to make and shape decisions in a complex economic and social environment. However, at the same time, and potentially reflecting alternative narratives from within local government, there are those that suggest that the government's approach is not unproblematic, for example with regard to the relationship between leadership and decision making structures. These academic debates serve to highlight some of the challenges and tensions that have been faced by the government in its promotion of 'strong leadership' and other elements of its modernisation agenda. The remainder of this article examines elements of the narratives that emerged from interviews with those in positions of political leadership in local authorities and the degree of fit, or otherwise, with those that have emerged from government.

\section{LEADERS’ NARRATIVES}

\section{Leadership style and structures}

Given the emphasis on 'strong leadership' in the government's narratives of reform and agenda for modernisation, including legislation, one of the areas of interest for this research was in the ways in which local political leaders perceive themselves as exercising leadership. Interestingly, among interviewees by far the most commonly used (unprompted) description of their leadership style was 'inclusive', used by nearly two-thirds, and this was followed by 'consensual', used by around half of respondents, while a number of others also used the term 'transparent'. These descriptions were used irrespective of party or type of authority, so that the Conservative leader of a county council who described themselves, in a close fit with the language frequently used by government, as a 'strong, visible leader' was in a very small minority.

Whilst the political make-up of councils inevitably impacted upon the ways in which leaders saw themselves as operating ('I believe in consensus. We do not have a whip. On a hung council you cannot do things confrontationally anyway; you need to discuss things' (Conservative, district council)) even leaders from majority groups chose to describe themselves as inclusive and consensual. In addition, these words were often used in conjunction with comparisons with their predecessors, either of different parties, such as, 'Officers have commented that this administration is less dictatorial than the previous' (Liberal Democrat, Welsh council), or the same party.

However, despite the different language used by leaders compared with that from central government, and whilst a number clearly felt uncomfortable with their perception of what the government had been seeking, 'strong leadership' is not necessarily incompatible with 
inclusive and consensual styles of leadership and decision making, and some respondents clearly identified with such a view, for example suggesting that 'I am more inclusive than the previous leader, less confrontational and more consensual. But I am willing to have conflict and make tough decisions' (Conservative, county council). Indeed, expressions of being consensual and inclusive were sometimes combined with assertions of leadership that came close to the language used by the government ('Inclusive... consensual - we have never had a vote in cabinet... [but] I do have strong opinions and express them' (Labour, London borough) and a willingness 'to make tough decisions', with words such as 'tough', strong' and 'assertive' being used, albeit much less frequently than 'consensual' and 'inclusive'.

Several leaders observed that they felt an element of accountability and responsibility in their leadership, but whilst the government's discourse around visibility and accountability has been about the relationship between leaders and the public, these comments were more closely tied to issues associated with collective decision making, so that one Liberal Democrat said, for example, that 'I like to be inclusive, consult with people and take a decision. I accept when I make a mistake' (county council), whilst a Conservative described their stance as 'Tough but fair... You need to stand by people if things get difficult' (district council). A number also noted the benefits of collective or corporate ways in which the cabinets worked, emphasising the 'good debates' and collective decision making. In one thoughtful response, the Labour leader of a district council made the point that 'You can't use the same behaviour in every situation, so whilst my natural inclination is towards a participatory style, sometimes you have to say "This is what I think you should do"'.

Thus it is possible to identify considerable overlap between the narratives of central government, and some of those emerging from academic discourse (such as Mouritzen and Svara, 2002), and the views of local political leaders on the desirability of 'strong leadership'. However, there is perhaps a greater degree of differentiation in relation to the political structures that are required for 'strong leadership', with council leaders clearly believing that it is possible to demonstrate strong leadership within inclusive, consensual and collective decision making mechanisms, and to that extent supporting and reflecting those academic narratives (for example, Steyvers et al (2008) and Leach et al (2005)) that have been somewhat sceptical of the emphasis on structural change.

\section{Leadership skills}

Whilst there may be some differences in the narratives around leadership style and decision making structures, there was a significant degree of convergence between the discourses emerging from central government (for example, the Councillors Commission, 2007), from local government organisations (such as the IDeA (2007) political skills framework) and the leaders interviewed, around the type of skills required for councillors and for leadership in contemporary local authorities.

Among leaders few phrases came up repeatedly, with the most commonly used terms being 'managerial' and 'communication' skills, each cited by around one third of the sample. Managerial skills were seen as important for a variety of reasons, including: the need to prioritise and set the agenda for authorities, 'You need to be an original creative thinker, to be able to "cut through the crap", to identify priorities and issues. You need to be managerial' (Conservative, county council), and several leaders referred to the need to be able to think strategically, in particular in relation to planning and prioritising the work of their authorities; managing colleagues, 'You need to be able to manage politicians; make them feel that they are part of a team' (Independent, Welsh council); and managing officers, 'It is important to learn how to handle officers. You need to ensure that you do not get side-tracked' (Labour, unitary council). 
Similarly communication skills were identified as important, both for specific audiences, particularly the party groups on the councils ('You need to communicate, keep people with you, keep the Group aware of your reasons' (Conservative, district council)) and for the range of different audiences that council leaders are required to address: 'You have got to have good communication skills - be able to speak on different levels' (Conservative, district council).

In this sense, there were also clear reflections of academic narratives that emphasise the complexity of governance (Borraz and John, 2004) and the need for facilitative leadership (Gains et al, 2007) and the type of skills that might be appropriate for these.

However, despite this broad agreement, and indeed the greater availability of training for councillors than in the past, many leaders made clear that they had felt unprepared on assuming their roles. For many it was the breadth of the position that was seen as the major challenge: 'Initially it was overwhelming - I needed to know about everything' (Labour, Scottish council); others identified particular aspects of the role: 'Nothing prepares you for being a political leader; a cabinet role, and so on, gives you some idea, but you have to develop a thick skin. You need a combination of managerial skills and political skills... Dealing with the media has been difficult' (Conservative, county council) and 'It has been a very interesting experience. You need specific skills which I had not got' (Independent, Welsh council). In some cases the make-up of the council was seen as adding to the problem: 'I was not prepared for it. It was a hung council and had a new leader and new deputy. We had to start from the beginning. There is so much going on in the council... You need to know about everything...' (Conservative, district council). Even for some of those who had held significant posts, such as cabinet membership, prior to becoming leader, 'It took four to five months to get familiar with all the roles' (Conservative, county council).

A number suggested that fora such as the IDeA and CoSLA were valuable, both for the training that they provided ('the IDEA leadership academy was very useful' (Conservative, county council)) and because 'You can ask things that you could not ask in your council' (Labour, Scottish council). However, whilst recent years have seen a significant increase in and availability of training for councillors, with the growing emphasis upon the executive role of leaders, the widespread view among leaders of their inadequate preparation, may raise questions about the efficacy of a system that might accelerate the movement of individuals into positions of local political authority with less experience than has historically been the case, and also suggest the consequent desirability of providing appropriate and timely training and support for those affected.

\section{Leadership and power}

Where leaders' relationships with and powers over cabinets were concerned there was again a reflection of the emphasis in the government's discourse on strong leadership, and the executive arrangements introduced in the Local Government and Public Involvement in Health Act 2007, and the distinct academic narratives around strong leadership and the relationships between leadership and political structures, in that the narratives emerging from leaders tended to emphasise a desire for greater power, but at the same time they suggested that the current reality more closely reflected Leach et al's (2005) references to the importance of context and to personal capabilities, outlined earlier, as well as the constitutional decisions made by councils and by party groups, and arguably, the realities of local politics. Whilst a Conservative leader of a county council was able to say that 'The leader chooses the cabinet. It has been a bit hairy. People do not like losing their say. There are discussions about who gets portfolios. Nobody has refused a portfolio. I want cabinet skills rather than subject knowledge', a Labour leader of a unitary authority recognised the different interests of leaders and other councillors, and the irony of having previously opposed, as a matter of principle, a leader having the power to choose the cabinet: 'I wish I did. Now the group decides. The leader's recommendation is generally, but not always, 
accepted'. Another said that 'Our group, or most groups, decided that the executive would be open to election. I often wish, privately, that I had the gift of deciding who my executive colleagues were' (Labour, district council). Similarly a Conservative county council leader argued against the position in his authority where the council had to agree the distribution of portfolios: 'The Leader has to work with the Cabinet so should have the complete say'. A Liberal Democrat had managed to adjust the system: 'Prior to my being leader the group decided, but that didn't always work. I persuaded them to elect nine people to the Cabinet and then I talked to each of them to agree portfolios' (county council). From another perspective, a Liberal Democrat cabinet member on a unitary authority, asked whether she had a choice of portfolio, responded 'Yes and no. It is debated among the group and depends what people's interests and skills are'; but another was clear that 'It is the leader who decides who gets which portfolio' (Conservative, county council).

For obvious reasons, authorities with no overall control posed particular challenges. On one district authority, where three parties and Independents were involved in sharing power, the Conservative leader of the council said that 'the leaders of groups (and deputies) get together and put together a proposal for council, then the leader chooses who has which portfolio'. A similar pattern, with groups making decisions about who should be on the cabinet, but the leader determining portfolios, appeared relatively common on many councils, and particularly in those with no overall control. In one instance the leader said 'I have the power, but have always discussed it with my deputy, and then I have to go to the Liberal Democrats [partners in power sharing]' (Conservative, county council). In Scotland, where the committee system remains in place in most authorities, a similar pattern emerged, with sometimes complex negotiations, particularly in authorities with no overall control ('There was negotiation with the Liberal Democrats - they have [a committee chair]... We got the Conservatives on side on non-political issues' (Labour, Scottish council). The increase in the number of such authorities following the introduction of the single transferable vote in 2007, is likely to have reinforced this position.

Overall, the general impression emerging from the narratives of council leaders in this regard is, perhaps inevitably, of a considerable degree of discussion and negotiation, even on those authorities where the leader possesses the constitutional power to choose the cabinet and to allocate portfolios. There is, therefore a degree of support for the narratives associated with Steyvers et al's (2008) questions about the relationship between institutional reform and leadership in practice, and Borraz and John's view that 'stronger leadership models do not necessarily entail systematically a more personal style of decision-making... Leaders rarely act alone and the move towards stronger leadership models could very well foster more collegial practices' (2004: 113), and perhaps implicitly for Gains et al's (2007) model of facilitative leadership.

\section{CONCLUSIONS}

Whilst the focus of this article has been on the reforms and discourse of the Labour government, and its relationship with the narratives that emerge from council leaders, it is perhaps worth briefly considering the positions of the other major parties. Perhaps unsurprisingly, given that they are in Opposition, there is a lack of specificity in the ideas put forward by them. The Liberal Democrats, in their policy paper, The Power to be Different, undertook to allow councils to determine their own constitutional arrangements, including abolishing the requirement for a split between executive and scrutiny functions and allowing for councils which desired it, to return to a committee based structure (Liberal Democratic Party, 2007). It is therefore unclear what the impact of this would be on local political leadership. Where the Conservative Party is concerned, their green paper, Control Shift Returning Power to Local Communities, says relatively little about decision making processes and structures. It does, in places, repeat elements of the New Labour discourse, so that 'In our 
biggest cities, there is a strong case for new powers being placed in the hands of a single accountable individual - an elected Mayor who can provide the city with strong leadership. Individual leadership of these councils can benefit local citizens by improving the clarity of municipal decision-making and enhancing the prestige of their city' (Conservative Party, 2009: 20). In others, it follows the Liberal Democrats in proposing to give other councils the ability to decide what decision making structures they would like to adopt, subject to a local referendum. In reality, given the requirement to hold a referendum, it would seem likely that the status quo would be likely to dominate for a period at least. Whilst in some respects it might therefore be argued that the Conservative narrative is currently broad enough to fit more easily with that of council leaders, outside the major cities it does not appear to reflect the wishes of leaders for greater powers over cabinets, for example, and the likely impact of the implementation of such an approach is far from clear.

The results of this research demonstrate that there are significant levels of convergence between the discourses of central government under Labour with regard to local political leadership and those that emerge from the narratives of council leaders, as well as academic work that sees strong leadership as an understandable and appropriate response to the changing needs of local and national politics. There also appears to be a broad consensus on the type of skills required by councillors and leaders, although the research highlights the difficulties of providing adequate training and preparation when individuals can be catapulted into positions of leadership with only limited experience and with almost no notice.

At the same time, there are some areas of divergence, perhaps most notably around the relationship between political structures and political leadership and decision making, where leaders tend to produce views that fall somewhat closer to those elements of academic narratives that differentiate between practices and position (such as Haus and Sweeting, 2006) and those that are less convinced that structural change will necessarily provide the type of leadership sought by the government (including Lowndes and Leach, 2004) . For example, as noted earlier, the great majority of those interviewed clearly see their role and styles as being facilitative and inclusive in at least some respects, whilst the impact of context and personal capabilities discussed by Leach et al (2005), and the potential for conflict with local parties and party groups (Copus, 2004; Leach and Wilson, 2008) is also apparent.

*The authors are grateful to the Nuffield Foundation Small Grants Scheme for their support for this research under grant number SGS/32112, and to the councillors who agreed to be interviewed. They are also grateful to two anonymous referees for their constructive comments on an earlier draft of this article. 


\section{REFERENCES}

Bacchi, C. (1999) Women, Policy and Politics: The Construction of Policy Problems (London: Sage).

Borraz, O. \& John, P. (2004) The Transformation of Urban Political Leadership in Western Europe, International Journal of Urban and Regional Research, 28(1), pp.107-20.

Conservative Party (2009) Control Shift - Returning Power to Local Communities (London: Conservative Party).

Copus, C. (2004) Directly Elected Mayors: A Tonic for Local Governance or Old Wine in New Bottles?, Local Government Studies, 30(4), pp.576-8.

Coulson, A. (2004) Local Politics, Central Power: The Future of Representative Local Government in England, Local Government Studies, 30(4), pp.467-80.

Councillors Commission (2007) Representing the future: The report of the Councillors Commission (London: DCLG).

Department for Communities and Local Government (2006) Strong and Prosperous Communities (London: The Stationery Office).

Department for Communities and Local Government (2007) Strong and Prosperous Communities - The Local Government White Paper Implementation Plan: One Year On (London: DCLG).

Department for Communities and Local Government (2008) Creating Strong, Safe and Prosperous Communities: Statutory Guidance (London: DCLG).

Department for Communities and Local Government (2009) Strong and prosperous communities - The Local Government White Paper: Final implementation plan (London: DCLG).

Gains, F., Greasley, S., John, P. \& Stoker, G. (2007) Does Leadership Matter: A Summary of Evidence on the Role and Impact of Political Leadership in English Local Government (London: DCLG).

Goldsmith, M. \& Larsen, H. (2004) Local Political Leadership: Nordic Style, International Journal of Urban and Regional Research, 28(1), pp.121-33.

Haus, M. \& Sweeting, D. (2006) Local Democracy and Political Leadership: Drawing a Map, Political Studies, 54(2), pp.267-88.

Improvement and Development Agency (2007) The Political Skills Framework: A Councillor's Toolkit (London IDeA).

Laffin, M. (2008) Local Government Modernisation in England: A Critical Review of the LGMA Evaluation Studies, Local Government Studies, 34(1), pp.109-25.

Leach, S., Hartley, J., Lowndes, V., Wilson, D. \& Downe, J. (2005) Local Political Leadership in England and Wales (York: Joseph Rowntree Foundation).

Leach, S. \& Wilson, D. (2008) Diluting the Role of Party Groups? Implications of the 2006 Local Government White Paper, Local Government Studies, 34(3), pp.303-21. 
Liberal Democratic Party (2007) The Power to be Different (London: Liberal Democratic Party).

Lowndes, V. \& Leach, S. (2004) Understanding local political leadership: constitutions, contexts and capabilities, Local Government Studies, 30(4), pp.557-75.

Mouritzen, P-E. M. \& Svara, J. (2002) Leadership at the Apex (Pittsburgh: Pittsburgh University Press).

Newman, J. (2001) Modernising Governance (London: Sage).

Office of the Deputy Prime Minister (2005) Vibrant Local Leadership (London: ODPM).

Orr, K. (2004) If Mayors are the Answer then What was the Question?, Local Government Studies, 30(3), pp.331-44.

Orr, K. (2005) Interpreting Narratives of Local Government Change under the Conservatives and New Labour, British Journal of Politics and International Relations, 7(3), pp.371-85.

Rao, N. (2005) Councillors and the New Council Constitutions (London: ODPM).

Rao, N. (2006) Modernising Local Government, Economic Affairs, 26(1) pp.18-24.

Steyvers, K., Bergström, T., Bäck, H., Boogers, M., de la Fuente, J. \& Schaap, L. (2008) From Princeps to President? Comparing Local Political Leadership Transformation, Local Government Studies, 34(2), pp.131-46.

Wollmann, H. (2008) Reforming Local Leadership and Local Democracy: The Cases of England, Sweden, Germany and France in Comparative Perspective, Local Government Studies, 34(2), pp. 279-98. 